\title{
PENGINTEGRASIAN KEARIFAN LOKAL SUBAK ABIAN CATU DESA SAMBIRENTENG BULELENG BALI SEBAGAI SUMBER BELAJAR IPS DI SMP
}

\author{
I Nyoman Mantaka ${ }^{1}$, Luh Putu Sendratari², Ketut Margi ${ }^{3}$ \\ Program Studi Pendidikan IPS Universitas Pendidikan Ganesha Singaraja \\ e-mail: mantakainyoman@gmail.com ${ }^{1}$, Ipsendra@yahoo.co.id² $^{2}$, \\ ketut.margi@yahoo.co.id.pasca.undiksha..ac.id ${ }^{3}$
}

\begin{abstract}
Abstrak
Penelitian ini dilatar belakangi adanya upaya untuk mewujudkan pembelajaran IPS yang inovatif berwawasan lingkungan yang berorientasi pada pelestarian budaya Subak. Tujuan penelitian adalah (1) memahami latar belakang pengintegrasian nilai-nilai kearifan lokal Subak Abian Catu sebagai sumber belajar IPS, (2) mengidentifikasi nilai-nilai kearifan lokal yang dianut di dalam Subak Abian Catu, (3) menemukan mode mengintegrasikan kearifan lokal Subak Abian Catu sebagai Sumber belajar IPS. Rancangan penelitian yang digunakan adalah research and development dengan tiga tahap yaitu define, design, dan develop. Pengumpulan data menggunakan teknik observasi, wawancara, analisis dokumen..Hasil penelitian menunjukkan bahwa (1) pentingnya nilai-nilai kearifan lokal Subak sebagai sumber belajar karena adanya pesan moral tentang idiologi hijau dan pesan humanis untuk menjaga kelestarian alam dan kerjasama. (2) Nilai-nilai kearifan lokal Subak abian catu yang berpotensi sebagai sumber belajar IPS meliputi; sikap hormat terhadap alam, tanggung jawab, solidaritas kosmis, kasih sayang, perduli terhadap alam, tidak merugikan/merusak, hidup sederhana, keadilan, demokratis, dan integritas moral.I. (3) Pengintegrasian kearifan lokal subak sebagai sumber belajar IPS menggunakan model pengintegrasian berdasarkan potensi utama, dalam bentuk perangkat pembelajaran RPP dan Handout,dan dari hasil uji kelayakan produk RPP dan Handout berkatagori baik, layak untuk dijadikan sumber belajar dalam pembelajaran IPS.
\end{abstract}

Kata kunci :Kearifan Lokal Subak, Sumber Belajar

This was based on the effort to realize an innovative environmentally insigth's social science learning that it was oriented to the preservation of Subak culture. The objectives of the research was (1) to understand the background of integrating the values of local wisdom of Subak Abian Catu as social science learning resource, (2) to identify local wisdom values of Subak Abian Catu, (3) to find modes to integrate local wisdom of Subak Abian Catu as social science learning resource.The research design used research and development with three stages such as define, design, and develop.. Data was collected by observation, interview, document analysis. The result showed that (1) local wisdom of subak was importance as an environmentally insight's learning source because there was the moral message about green idiology and the humanist message to preserve nature and cooperation. (2) The values of Subak Abian Catu's local wisdom which have potential as social science learning resources include; attitude of respect for nature, responsibility, cosmic solidarity, compassion, caring for nature, no harm, simple life, justice, democracy, and moral integrity. (3) The integration of Subak's local wisdom as social science learning resource using integration model that it based on the main potential learning materials, RPP, and handout and from the results of the feasibility test as RPP and Handout products with good category, it is feasible to be a learning resource in IPS learning.

Keywords:Local Wisdom of Subak, Learning Sources

\section{PENDAHULUAN}

Subak merupakan salah satu aset kelembagaan tradisional yang telah terbukti efektifitasnya dalam menyangga pembangunan pertanian, perkebunan dan peternakan di Bali. Subak juga merupakan warisan budaya yang ada di Bali yang sangat perlu untuk dijaga kelestariannya, karena memiliki peran pengaturan institusional yang disusun selama berabad-abad melalui beberapa rangkaian percobaan yang dilakukan petani untuk mendistribusikan dan mengelola air dari sumbernya/mata air. 
Pengertian Subak menurut Perda Provinsi Bali No. 9 Tahun 2012, subakadalah organisasi tradisional dibidang tata guna air di tingkat usaha tani pada masyarakat adat di Bali yang bersifat sosio agraris, religius, ekonomis yang secara historis terus tumbuh dan berkembang.Meskipun subakadalah sistem irigasi yang khas di Bali dijiwai oleh agama Hindu, terutama karena upacara ritual keagamaan yang senantiasa menyertai setiap aktivitasnya tetapi Subak juga memiliki nilai-nilai luhur yang bersifat universal dan sangat relevan dengan konsep pembangunan berkelanjutan.Nilai-nilai tersebut adalah falsafah Tri Hita Karana yang melandasi setiap kegiatan subak.Nilai-nilai yang ada pada Subak merupakan nilai-nilai kearifan lokal, yang layak untuk dilestrikan dan juga perlu diwariskan pada generasi muda atau peserta didik dalam dunia pendidikan.

Memperkenalkan nilai-nilai kearifan lokal pada dunia pendidikan adalah salah satu inovasi yang baik untuk dilakukan, karena pendidikan berbasis kearifan lokal adalah pendidikan yang didasarkaan kepada pengayaan nilai-nilai kultural. Pengelolaan kegiatan pembelajaran, guru hendaknya memberikan kesempatan kepada peserta didik untuk memaknai dan mengelola apa yang mereka pelajari dan mampu menerapkan dalam dunia nyata. Dalam hal ini, pemilihan sumber belajar mesti dikaitkan dengan minat dan keinginan peserta didik, sudah tentunya bahwa sumber belajar yang paling banyak terdapat pada lingkungan peserta itu sendiri. Maka dari itu perlu melibatkan lingkungan peserta didik sebagai salah satu sumber belajar nyata yang mudah dipahami peserta didik

Pada dasarnya kita tidak bisa memungkiri bahwa begitu tingginya nilai-nilai kearifan lokal yang dimilikinya, untuk itu keberadaan Subak menjadi hal yang harus dijaga, karena organisasi yang sosio-kultural ini juga memiliki kelemahan-kelemahan seperti ketidak sanggupan untuk menahan intervensi dari pihak luar, khususnya yang berkaitan dengan alih fungsi lahan yang sangat deras. Banyak dijumpai tanah-tanah subak yang masih produktif sudah beralih fungsi, seperti menjadi perumahan atau hotel.Tentu hal ini tak lepas dengan pertumbuhan penduduk yang cukup tinggi dan daya tarik pulau Bali sebagai daerah wisata. Apabila lahan semakin kecil akan berdampak pada pengelolaan sistim Subak menjadi kacau, dan apabila hal ini dibiarkan niscaya Subak akan mati dan Bali akan kehilangan sebagian dari kebudayaannya. DI samping itu berkurangnya minat generasi muda untuk bekerja sebagai petani.Selain karena dianggap pekerjaan yang kurang elit, bekerja sebagai petani tidak menjamin pendapatan yang memadai (Sutawan, 2003).

Sekarang ini terdapat 1546 Subak, yang terdiri dari Subak Sawah dan Subak Abian.Berdasarkan jumlahnya, 799 merupakan Subak Abian yang ada di Bali dan sisanya merupakan Subak Sawah sebanyak 747. Subak Sawah biasanya sebagian besar kawasan digunakan untuk bercocok tanam padi, dan Subak Abian sebagian besar wilayahnya digunakan untuk bercocok tanam tanaman kering seperti kelapa, kopi, dan beberapa tumbuhan lain. Subak Abian kurang begitu populer karena kiprahnya merupakan organisasi petani di daerah kering yang condong bergerak pada perkebunan dan peternakan.

Subak sebagai warisan budaya pertanian di Bali memiliki nilai-nilai yang sangat sesuai dalam konteks pendidikan. Di dalamnya tedapat nilai-nilai kearifan lokal seperti konsep Tri Hita Karana yang begitu mendunia karena di dalamnya tertuang ajaran untuk selalu menjaga keharmonisan.

Tidak bisa dipungkiri perhatian generasi muda terhadap pertanian ataupun Subak dewasa ini sangatlah kurang, untuk itu pengenalan Subak dan pengintegrasian Subak dalam pembelajaran IPS mempunyai arti yang sangat penting, utamanya pengenalan nilai-nilai kearifan lokal juga tek lepas dengan upaya pelestarian Subak itu sendiri.

Begitu pentingnya Subak dan begitu tingginya nilai-nilai yang dimiliki, sudah menjadi tanggung jawab bersama untuk melestarikannya.Salah satu upaya adalah dengan mengintegrasikan dalam pendidikan. Subak merupakan salah satu sumber yang bisa digunakan sebagai sumber belajar Pemanfaatan Nilai-nilai keaarifan lokal yang ada pada Subak dalam pendidikan menjadi hal yang sangat tepat, karena akan memiliki makna ganda baik dalam upaya pelestarian juga maupun pencapaian dalam pembelajaran yang lebih bermakna, sesuai dengan tujuan pembelajaran IPS di SMP.

Berkaitan dengan upaya pemanpaatan lingkungan sebagai sumber belajar, letak Subak Abian Catu Dasa Sambirenteng yang sangat berdekatan dengan SMP Negeri 2 
Tejakula, menjadi nilai lebih dan setrategis untuk menjdi tempat penelitian. Disamping itu penelitian mengenai nilai-nilai kearifan lokal sebagai sumber belajar belum pernah dilakukan di Sekolah ini ataupun pada Subak Abian.

Kemampuan untuk menciptakan proses pembelajaran agar berlangsung secara aktif interaktif perlu dikembangkan oleh guru, karena pembelajaran yang inovatif diarahkan untuk menghasilkan proses pembelajaran akan berlangsung dengan baik. Dewasa ini masih banyak guru yang belum bisa memanfaatkan sumber belajar dengan baik, sehingga proses pembelajaran berlangsung secara teoritis kurang aktual, sesuai apa yang akan dihadapi peserta didik di lingkungan sebenarnya di masyarakat.

Usaha untuk itu perlu dilakukan mengingat, pendidikan memberikanjalan terkait kemungkinan pada siswa untuk memperoleh kesempatan, harapan dan pengetahuan agar dapat hidup secara lebih baik. Besarnya kesempatan dan harapan sangat tergantung pada kualitas pendidikan yang ditempuh. Pendidikan yang berkualitas tentunya melibatkan siswa untuk aktif belajar dan mengarahkan terbentuknya nilai-nilai yang dibutuhkan oleh siswa dalam menempuh kehidupannya.( Sani Ridwan Abdulah:2015).

Pengenalan kearifan lokal yang ada dimasyarakat dalam dunia pendidikan masih sangat kurang, hal ini semestinya bisa dijadikaan solusi atau pilihan untuk pengembangan dalam pembelajaran, dengan memanfaatkan nilai-nilai kearifan lokal yang ada dalam masyarakat. Subak adalah salah satu kearifan lokal yang sudah dikenal di dunia dengan konsep Tri Hita Karana. Mengingat nilai-nilai yang terdapat pada kehidupan subak maka guru bisa berpikir maju untuk memanfaatkan hal itu dalam upaya peningkatan dalam pembelajaran, sehingga pembelajaran bisa berlangsung sesuai dengan apa yang ada sebenarnya atau lebih kontekstual, dan nilai-nilai subak bisa ditanamkan pada diri peserta didik.

Mengingat begitu banyaknya permasalahan dalam pembelajaran IPS seperti terbatasnya kemampuan guru dalam proses belajar mengajar dan kurangnya inovasi penggunaan sumber belajar dan juga faktor-faktor lain yang berkontribusi pada proses pembelajaran yang kurang inovatif dan bermuara pada rendahnya hasil belajar dalam pembelajaran IPS, maka penelitian ini akan dilaksanakan dengan mengkaji dan menguji "Pengintegrasian kearifan lokal Subak Abian Catu Desa Sambirenteng Buleleng Bali sebagai sumber belajar di SMP “.

Identifikasi masalah berdasarkan dengan latar belakang tersebut adalah, Pendidikan memberikan kemungkinan pada siswa untuk memperoleh kesempatan, harapan dan pengetahuan agar dapat hidup secara lebih baik.Besarnya kesempatan dan harapan sangat tergantung pada kualitas pendidikan yang ditempuh.

Subak adalah salah satu kearifan lokal yang sudah dikenal di dunia dengan konsep Tri Hita Karana. Mengingat nilai-nilai yang terdapat pada kehidupan subak tidak salah seandainya guru bisa berpikir maju untuk memanfaatkan hal itu dalam upaya peningkatan dalam pembelajaran, sehingga pembelajaran bisa berlangsung sesuai dengan apa yang ada sebenarnya ,dan nilai-nilai subak bisa ditanamkan pada diri peserta didik.

Berdasarkan hal di atas tentang Upaya untuk memecahkan masalah tersebut dilandasi oleh beberapa teori yang dianggap relevan dilandasi oleh teori kearifan lokal subak sebagai aktualisasi Tri Hita Karana dan budaya Bali. Pengintegrasian nilai kearifan lokal subak sebagai sumber belajar IPS dilandasi oleh teori IPS sebagai mata pelajaran di tingkat SMP, Pemilihan strategi pembelajaran oleh guru menjadi salah satu kunci untuk menciptakan proses pembelajaran baik, utamanya bagai mana guru bisa memanfaatkan atau menggunakan media dan sumbar belajar secara maksimal demi tercapainya tujuan pembelajaran. Pemanfaatan nilai-nilai kearifan lokal untuk sumber belajar merupakan salah satu usaha yang perlu dimanfaatkan demi pembelajaran berlangsung dengan aktif dan inovatif.

Bertalian dengan semua itu, penelitian ini bertujuan untuk (1) memahami latar belakang pengintegrasian nilai-nilai kearifan lokal Subak Abia Catu sebagai sumber belajar. (2) mengidentifikasi nilai-nilai kearifan lokal yang dianut dalam Subak Abian Catu. (3) menemukan mode/cara mengintegrasikan kearifan lokal Subak Abiab Catu Sebagai sumber belajar IPS. 


\section{METODE}

Pada penelitian ini, digunakan rancangan penelitian dan pengembangan (Research and Developmen).Metode pengumpulan data diklasifikasikan menjadi tiga yaitu (1) metode pengumpulan data pada tahap studi terkait nilai kearifan lokal Subak Abian Catu Desa Sambirenteng dengan observasi, wawancara dan analisis dokumen.Sumber data yaitu informan pekaseh Subak dan beberapa orang petani serta beberapa dokumen atau refrensi yang relevan.(2) Metode pengumpulan data tahap define,design, dan develop dengan observasi, wawancara dan analisis dokumen. Sumber data dari informan yaitu Kepala SMP Negeri 2 Tejakula dan Guru mata pelajaran IPS serta dokumen perangkat pembelajaran.(3) Mode/ cara pengintegrasian nilai kearifan lokal dalam pembelajaran pengumpulan data pada tahap uji kelayakan sumber belajar pada siswa dan guru terkait efektivitas pengembangan RPP dan sumber belajar yang dihasilkan dan dimanfaatkan dalam pembelajaran

\section{HASIL DAN PEMBAHASAN}

Terdapat tiga pokok bahasan darihasil penelitian, diantaranya sebagai berikut.

\section{LATAR BELAKANG PENTINGNYA PENGINTEGRASIAN NILAI-NILAI KEARIFAN LOKAL SUBAK ABIAN CATU SEBAGAI SUMBER BELAJAR DI SMP.}

Untuk memperoleh jawaban yang melatar belakangi pengintegrasian Nilai-nilai kearifan lokal Subak Abian Catu sebagai sumber belajar di SMP, tidak bisa lepas dengan tujuan dari pembelajaran IPS dan pemahaman siswa terhadap hal-hal penting yang ada di lingkungannya, seperti keberadaan Subak yang sudah mulai dilupakan oleh generasi muda.

Pengintegrasian Nilai-nilai kearifan lokal dilatar belakangi begitu banyaknya nilai-nilai filosofi yang sangat baik dan perlu diketahui oleh anak didik, dan nilai-nilai itu ada disekitar mereka menyangkut aspek sosial, budaya dan relegi.

Kearifan lokal adalah pengetahuan dan cara berpikir yang berakar dalam kebudayaan suatu kelompok manusia yang merupakan hasil pengamatan selama kurun waktu yang lama. Ridwan (2007) mengemukakan bahwa kearifan lokal dapat dipahami sebagai usaha manusia dengan menggunakan akal budinya (kognisi) untuk bertindak dan bersikap terhadap sesuatu, obyek atau peristiwa yang terjadi dalam ruang tertentu. Kearifan lokal mempunyai manfaat tersendiri dalam kehidupan masyarakat

Nilai-nilai kearifan lokal sangat perlu dilestarikan yang di dalamnya memuat aspek lingkungan, budaya dan relegi sebagai bagian dalam kehidupan manusia. Pengintegrasian pembelajaran dengan berwawasan lingkungan yang dekat dengan anak didik akan menjadikan pembelajaran berlangsung secara aktif dan inovatif. Dengan penggunaan sumber belajar yang ada pada lingkungan yang dekat dengan anak didik menjadikan pembelajaran lebih bermakna, artinya benar-benar bermanfaat bagi siswa dalam menghadapi kehidupan yang nyata di masyarakat

Dalam pembelajaran IPS dengan memanpaatkan Subak Abian Catu Desa Sambirenteng akan ditemukani nilai yang sangat tinggi maknanya sesuai dengan 3 aspek yang merupakan nilai-nilai kearifan lokal sebagai penjabaran dari filosofi Tri Hita Karana yang meliputi ; aspek teknik, aspek sosial dan aspek relegi,

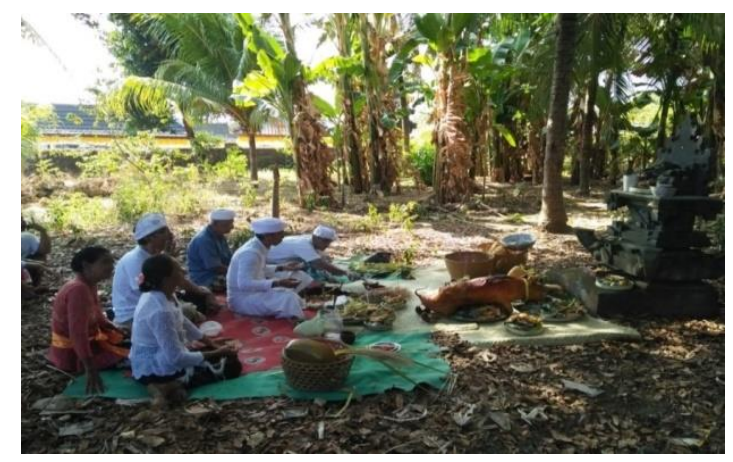

Gambar 1. Kegiatan Upacara keagamaan dibidang Pertanian (Sumber: Dok. Mantaka Nopember 2017) 
Pengintegrasian Nilai-nilai kearifan lokal juga dilatar belakangi karena nilai-nilai kearifan lokal Subak Abian Catu Desa Sambirenteng mengandung pesan moral tentang idiologi hijau yaitu ajaran untuk selalu menjaga kelestarian lingkungan dan pesan humanis yaitu untuk selalu menjaga keharmonisan atau kerjasama antar manusia. Karenanya banyak nilai-nilai kearifan lokal yang cocok digunakan sebagai sumber belajar, mengingat nilai-nilai yang diterapkan dalam pembelajaran, akan mendekatkan siswa pada masalah yang sebenarnya, sehingga pembelajaran benar-benar bermakna. Hal ini juga dapat dimanfaatkan sebagai upaya untuk melestarikan nilai-nilai yang mungkin tidak dikenal atau hampir punah.Dengan demikian nilai-nilai kearifan lokal bisa diwariskan pada anak didik sebagai penerus.

\section{NILAI-NILAI KEARIFAN LOKAL YANG DIANUT Di DALAM SUBAK ABIAN CATU}

Nilai-nilai kearifan lokal Subak Abian Catu Desa Sambirenteng, sangatlah penting untuk diketahui oleh peserta didik yang merupakan generasi penerus kita. Nilai-nilai kearifan lokal yang dimiliki hendaknya selalu terjaga, untuk itu memerlukan upaya maksimal dalam pelertarian.Pelestarian Subak menjadi tanggung jawab kita semua.Untuk hal ini kita perlu mengetahui dan memaknai nilai-nilai kearifan lokal yang dimiliki Subak Abian Catu Desa Sambirenteng.

Sebagai warisan budaya Subak Abian Catu, memiliki nilai-nilai kearifan lokal yang secara umum bisa tampak dalam tiga wujud kebudayaan seperti ;

1. Wujud sistim budaya,

Dalam Subak Abian Catu memuat akan konsep, ide, gagasan, dan norma aturan seperti; adanya Awig-awig Subak Abian Catu yang menjadi roh dan panutan dalam keberlangsungan kegiatan Subak.

2. Wujud sistim sosial.

Pada Subak Abian Catu bisa dilihat dengan adanya kegiatan gotong royong dan intraksi yang rutin dilaksanakan lewat rapat pengurus dan anggota yang dilaksanakan terjadwal setiap sabtu di akhir bulan

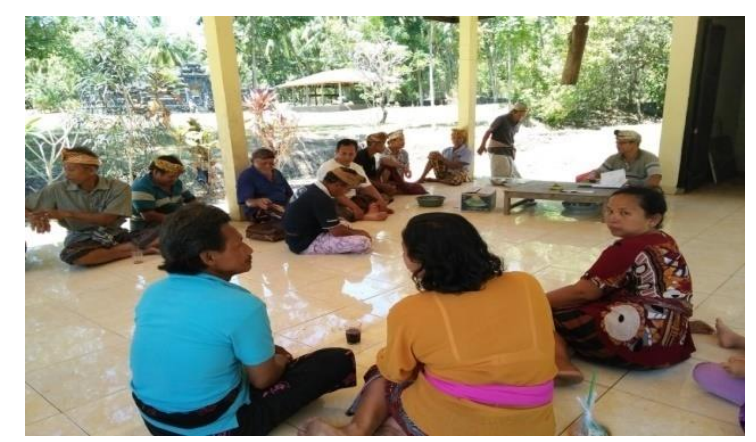

Gambar 2. Kegiatan Rapat Anggota Subak

(Sumber Dok. Mantaka Nopember 2017)

3. Wujud kebudayaan atau fisik.

Wujud fisik yang ada pada Subak Abian Catu bisa dilihat dengan adanya Pura Subak, Balai Subak dan yang paling khas yang ada di Subak Abian Catu adalah tempat suci yang ada di setiap lahan pertanian anggota yang disebut dengan inceman. Inceman merupakan tempat suci yang ada di setiap lahan tegalan petani yang dijadikan sebagai parahyangan untuk memohon pada tuhan disetiap memulai kegiatan pertanian atau berkebun. 


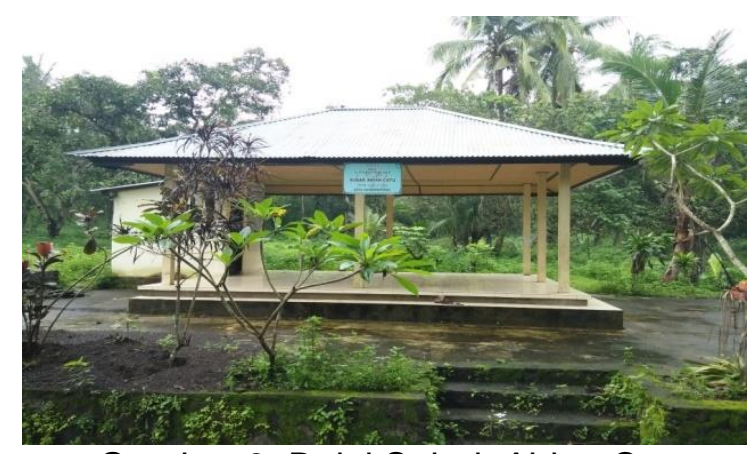

Gambar 3. Balai Subak Abian Catu

(Sumber: Dok. Mantaka, Nopember 2017)

Nilai-nilai kearifan lokal yang dianut didalam Subak Abian Catu Desa Sambirenteng, yang didapat dari hasil wawancara dan pengamatan, meliputi beberapa sikap atau prinsip yaitu :

1) Sikap Hormat Terhadap Alam.

Menjaga kelestarian alam menjadi tanggung jawab kita semua, karena kerusakan lingkungan akan berimbas bagi kita sendiri, untuk itu kita sebagai manusia harus memberikan hak kepada semua mahluk hidup, tumbuh dan berkembang secara ilmiah sesuai dengan habitatnya. .jadi kita harus bisa memberi kebebasan hidup, merawat, menjaga dan melindungi apa yang harus ada sebagai bagian dari ekosistem dalam kehidupan.

2). Sikap Tanggung Jawab

Tanggung jawab merupakan hal yang harus dimiliki oleh setiap orang, terkait itu menyangkut pribadi ataupun kepentingan umum, hal tersebut sebagai pencerminan rasa memiliki agar apa yang ada tetap berjalan sesuai dengan kesepakatan yang telah dibuat, sikap tanggung jawab tentunya perlu di bentengi dengan aturan-aturan yang memuat peringatan dan sangsi demi jalannya sebuah organisasi atau kesepakatan.

3). Sikap Solidaritas Kosmis

Sebagai masyarakat Bali, kita tidak bisa lepas dengan cerita-cerita yang bersifat kosmis atau dalam istilah Bali yang berbau mitos atau relegi yang masih dianut yang tentunya mempunyai nilai positif dalam kehidupan masyarakat.Karena sikap ini justru bisa menjaga kelestarian lingkungan alam, atau keharmonisan manusia dan alam.

4). Sikap Kasih Sayang dan Kepedulian Terhadap Alam .

Sikap kasih sayang dan kepedulian terhadap alam adalah prinsip moral satu arah , menuju yang lain, tanpa mengharapkan balasan.(Keraf,2002) Kesemuanya yang dilakukan bukan merupakan kepentingan pribadi, melainkan untuk semua dan alam yang ada disekitarnya.penanaman sikap kasih sayang ini memang harus ditumbuhkan sejak dini ditunjang juga dengan lingkungan yang baik,

5). Sikap Tidak Merugikan Atau Merusak

Manusia pada dasarnya harus memiliki Sikap tidak merusak, sikap moral untuk tidak merusak perlu ditanamkan pada setiap orang, merusak lingkungan pada akhirnya akan merugikan kita sendiri, karena manusia hidup sangat teergantung dengan alam, manusia merupakan bagian dari alam itu sendiri. Keberlangsungan hidup mahluk hidup sangat tergaantung akan baiknya Habitat atau pun Ekosistem yang ada, sehingga mahluk hidup bisa berkembang biak dengan baik.

6). Sikap hidup Sederhana dan Selaras dengan Alam

Sikap Sederhana merupakan nilai atau cara hidup dengan pola yang tidak berlebihan, berupaya hidup sesuai dengan kemampuan yang ada utamanya sebagai masyarakat petani, yang mana pendapatannya yang masih belum mencukupi. Untuk itu upaya peningkatan pendapatan perlu diupayakan dengan memanfatkan keberadaan organisasi 


\section{7). Sikap Keadilan.}

Sikap adil merupakan suatu prilaku yang sangat diharapkan sebagai warga Negara. Manusia adalah mahluk sosial yang tidak hidup sendiri, sehingga tidak bisa semena-mena. Karena dibalik hak kita ada hak orang lain, kita mesti tahu hak dan kewajiban kita sendiri , karena kita bisa bersikap adil kepada siapapun ataupun alam sekitar niscaya keberadaan kita akan lebih baik.

\section{8). Sikap Demokratis}

Sikap Demokratis merupakan suatu sikap memberikan peluang seluas-luasnya akan adanya perbedaan atau keanekaragaman yang akan terjadi. Dan untuk itu kita harus menghormati adanya perbedaan pendapat yang ada yang mungkin tumbuh dalam kegiatan atau rapat organisasi.

9). Sikap Integritas Moral

Keberada Suatu organisasi tidak bisa lepas akan status legal atau resminya atas keberadaan berdirinya organisasi, mengingat organisasi akan semakin mendapat kepercayaan apa bila pendiriannya mendapatkan legalitas dari pihak yang terkait. Sehingga dalam melakukan sesuatu akan lebih terarah dan mendapatkan kepercaayaan.

\section{PENGINTEGRASIAN NILAI-NILAI KEARIFAN LOKAL SUBAK CATU SEBAGAI SUMBER BELAJAR IPS}

Mode atau cara pengintegrasian materi yang dianggap sesuai dengan memanfaatkan Subak Abian Catu Desa Sambirenteng sebagai Sumber belajar, model pengintegrasian materi berdasarkan potensi utama. Alasan utamanya yaitu, sesuai dengan hasil observasi dokumen silabus, Setandar kopetensi dan kompetensi dasar serta lingkup materi ajar, Selanjutnya, potensi Subak Abian Catu dianalisis komponen-komponennya yang berpotensi untuk dijadikan dasar pengembangan Sumber belajar dalam bentuk handout materi dan RPP , sesuai yang digambarkan pada gambar 1 bentuk pengintegrasian materi berdasarkan potensi utama, sebagai berikut.

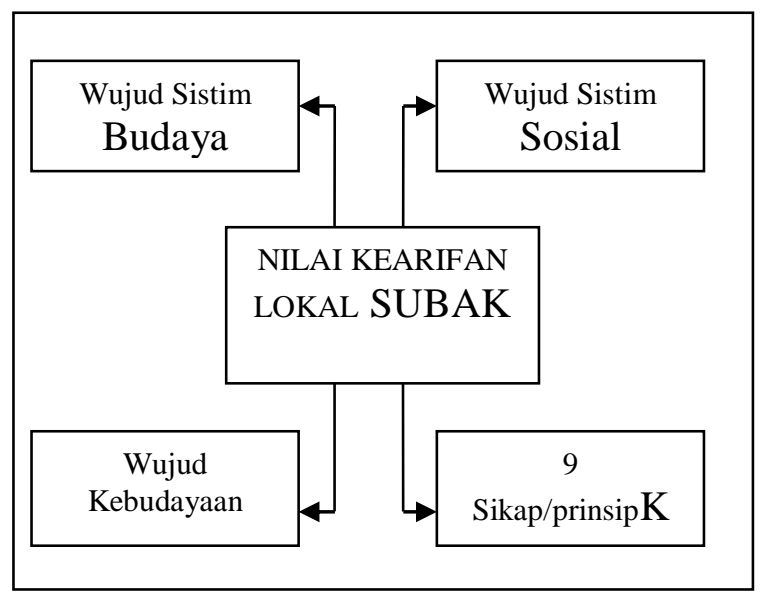

Gambar 1 model pengintegrasian nilai kearifan lokal subak sebagai sumber belajar IPS.

Lewat proses belajar mengajar, diharapkan dapat mengkaji potensi yang ada di lingkungan siswa, seperti nilai kearifan lokal subak abian Catu, sehingga siswa atau peserta didik dapat lebih memahami kondisi daerah atau Ingkungannya sekaligus memahami nilainilai kearifan lokal Subak Abian Catu Desa Sambirenteng, berkaitan upaya pencapaian kompetensi dasar pada mata pelajaran IPS.

Pengintegrasian dilaksanakan dengan memanfaatkan potensi utama Subak sebagai warisan budaya, dijadikan sebagai sumber belajar mengingat banyak nilai-nilai yang perlu dipelajari dan diwariskan pada generasi muda atau pelajar berupa nilai-nilai kearifan lokal.

Pengintegrasian nilai kearifan lokal Subak Abian Catu dalam pembelajaran IPS di SMP merupakan upaya usaha sadar guru agar pembelajaran bisa berlangsung lebih baik, 
inovatif, karena pembelajaran yang ditampilkan berwawasan lingkungan yang akan menjadikan pembelajaran lebih bermakna karena akan bermanpaat bagi siswa dalam kehidupannya di masyarakat. Pengintegrasian dalam pembelajaran merupaka upaya pelestarian nilai-nilai kearifan lokal, yang perlu dilakukan agar siswa mampu mengenal lingkungan dan daerah dimana ia berada, sehingga dapat mengambil nilai-nilai kearifan lokal itu dalam kehidupan nyata dan memanfaatkannya.

1) Pengembangan Rencana Pelaksanaan Pembelajaran

Penyusunan RPP yang telah dikembangkan lewat langkah-langkah sebagai berikut :

a). Menganalisa SK/KD dilakukan agar dapat mengintegrasikan dengan nilai-nilai kearifan lokal yang ada pada Subak. Materi yang ada diharapkan bisa terintegrasi dengan materi yang berisikan nilai-nilai kearifan lokal Subak Abian Catu Desa Sambirenteng.

Standar Kompetensi yang dipilih: "Memahami perubahan sosial," dengan Kopentensi dasar: "Mendiskripsikan perubahan sosial budaya pada masyarakat", dalam materi "perubahan sosial", Ini merupakan materi di kelas IX semester ganjil. Pemilihan materi kaitannya dengan SK dan KD, sangat terkait dengan pengembangan materi yang akan di integrasikan dengan nilai-nilai kearifan lokal Subak Abian Catu.

Subak sebagai warisan budaya yang sangat perlu diketahui oleh generasi muda utamanya siswa, karena nilai-nilai kearifan lokal yang sangat penting dan bernilai adiluhung, yang sangat disayangkan kalau hal itu sampai punah atau hilang karena adanya gempuran dari luar, yang merupakan dampak dari pada perubahan sosial. Perubahan sosial disamping berdampak positif juga berdampak negatif, untuk itu upaya pelestarian nilai-nilai kearifan lokal Subak Abian Catu perlu dilakukan dengan pengintegrasian nilai-nilai kearifan lokal Subak sebagai sumber belajar.dalam pembelajaran IPS

b) Upaya langkah-langkah pengembangan silabus, penyusunan RPP dalam rangkan pengintegrasian nilai-nilai kearifan lokal Subak dalam pembelajaran IPS, dengan memperhatikan : 1) Rumusan tujuan pembelajaran dikembangkan dengan penanaman nilainilai kearifan lokal Subak, disamping tujuan pembelajaran harus sesuai dengan tingkat perkembangan peserta didik. 2). Pendekatan atau metode pembelajaran dapat memfasilitasi peserta didik mencapai pengetahuan dan ketrampilan juga menguasi nilai-nilai kearifan sosial Subak. 3). Penggunaan bahasa harus sesuai kaidah bahasa Indonesia, dan mudah difahami.

\section{2). Hasil Pengembangan Sumber Belajar}

Pengembangan suplemen atau sumber belajar diambil dari buku ajar atau buku paket yang menjadi buku wajib di sekolah. Penggunaan buku ajar selama ini dilihat dari materinya masih kurang akan nilai-nilai lingkungan, dimana siswa itu berada, oleh karena itu pengintegrasian nilai-nilai kearifan lokal menjadi hal yang penting untuk dimasukkan sebagai sumber belajar. Hal ini dilakukan dengan mengadaftasi atau menambahkan pada materi yang sudah ada yang isinya masih merupakan satu bagian atau substansi yang sama, dengan materi yang ada pada silabus.Pengembangan bahan ajar atau Handout ini merupakan strategi sumber belajar tambahan yang dilaakukan guru untuk mengefektivitas peserta didik

Langkah-langkah yang ada dalam pengembangan Handout, dilakukan dengan kegiatan awal melalui menganalisa isi dari silabus, SK/KD yang kemudian akan bermuara pada penyusunan RPP. Pengintegrasian nilai-nilai kearifan lokal Subak Abian Catu, dikembangkan dengan mengaitkan dengan materi yang ada dalam KD, tentang "perubahan sosial budaya" dalam masyarakat. Karena dalam perubahan sosial budaya, tentu akan membawa dampak pada kehidupan sosial budaya yang ada dalam masyarakat. Untuk itu

Upaya untuk melestarikan nilai-nilai kearifan lokal yang ada pada Subak menjadi tanggung jawab kita semua .Untuk itu upaya pelestarian nilai-nilai budaya perlu dilakukan, seperti nilai kearifan lokal Subak Abian Catu Desa Sambirenteng. Ada beberapa nilai-nilai kearifan lokal Subak Abian Catu Desa Sambirenteng, yang dapat dijadikan atau diintegrasikan sebagai sumber belajar seperti: 1) dilihat dari wujud budaya, Subak Abian Catu memiliki tiga wujud kebudayaan: a) wujud sistim budaya, b) wujud sistim sosial, c) wujud fisik kebudayaan. Dan Subak Abian Catu memiliki nilai-nilai kearifan lokal dengan 
prinsip atau sikap: hormat terhadap alam, tanggung jawab, solidaritas kosmis, kasih sayang dan peduli terhadap alam, tidak merugikan atau merusak, hidup sederhana dan selaras dengan alam, keadilan, demokratis dan integrasi moral.

Pengembangan RPP dan sumber belajar berupa handout telah diterapkan pada siswa SMP Negeri 2 Tejakula pada siswa kelas IX semester ganjil, telah memberikan antusiasme dalam pembelajaran, dari uji kelayakan yang dilakukan dengan meminta tanggapan dari siswa dan beberapa guru, sudah mendaopatkan tanggapan positif,

Penggunaan suplemen sumber belajar dengan pengintegrasian nilai-nilai kearifan lokal Subak, mendapatkan tanggapan dari siswa bahwa: pembelajaran berlangsung lebih menarik karena adanya materi baru, yang memberikan wawasan baru akan nilai-nilai kearifan lokal subak yang selama ini, kurang dikenal olah siswa, secara umum siswa mengenal sedikit tentang subak sawah, sedangkan kita tahu subak ada dua yaitu subak sawah dan subak abian. Pendapat Guru berkaitan dengan hal ini dinyatakan bahwa; penerapan suplemen yang berwawasan lengkungan menjadi hal baru bagus dan inovatif, di samping masih jarang diterapkan. dan perlu dikembangkan, dilihat dari keterkaitan dengan SK dan KD dan cakupan materi sudah padu Isinya sudah sesuai dengan tujuan pembelajaran dengan memadukan materi pokok dengan nilai-nilai kearifan lokal subak. Merupakan hal baru atau mutahir mengingat sumber belajarnya vareatif, yaitu berwawasan lingkungan yang dekat dengan kehidupan siswa, sehingga meningkatkan rasa ingin tahu siswa.

Persiapan perangkat pembelajaran dalam kegiatan pembelajaran di kelas yang mengintegrasikan nilai-nilai kearifan lokal Subak Abian Catu dalam pembelajaran IPS, dengan pengembangan perencanaan pembelajaran (RPP). Hal ini dilakukan sebagai upaya untuk mempermudah guru untuk mengintegrasikan nilai-nilai kearifan lokal Subak dalam pembelajaran sehingga dapat mengaktualisasikan dan mengidentifikasi nilai-nilai kearifan lokal yang ada pada Subak Abian Catu Dasa Sambirenteng.

Hasil penilaian kelayakan dari validator ahli dan praktisi guru, terhadap RPP sebagai uji kelayakan yang terdiri dari 6 indikator dan 13 butir aspek yang dinilai yang diberkan oleh guru SMP Negeri 2 tejakula, sebagai praktisi pendidikan yang memiliki kemampuan di bidangnya menyatakan bahwa RPP yang dikembangkan termasuk dalaam katagori baik. Demikian juga tentang pengembangan sumber belajar berupa Handout telah dilakukan uji kelayakan dan penilaian dinyatakan, pengembangan sumber belajar termasuk dalam katagori baik juga. Sehingga sumber belajar berhak untuk diuji cobakan dalam pembelajaran.Dari hasil penilaian siswa dan pendapat siswa bahwa sumber belajar yang digunakan telah layak atau baik sebagai sumber belajar.

\section{PENUTUP}

Berdasarkan pembahasan dan analisa pada Bab sebelumnya dan berpatokan pada rumusan masalah berkaitan pengintegrasian nilai-nilai kearifan lokal Subak Abian Catu Desa Sambirenteng, dapat disimpulkan bahwa : Pengintegrasian nilai-nilai Subak Abian Catu Desa Sambirenteng menjadi hal yang sangat penting untuk dilakukan karena dilatar belakangi bahwa perlunya upaya untuk melestarikan nilai-nilai kearifan lokal yang kita miliki mengingat nilai-nilai yang dimiliki memiliki makna yang cukup tinggi yang sangat dikagumi dunia sebagai warisan budaya, upaya itu bisa dilakukan dengan menjadikan nilai-nilai kearifan lokal Subak sebagai sumber belajar dalam pembelajaran IPS.

Pembelajaran IPS pada siswa dengan memanfaatkan lingkungan yang dekat dengan anak didik menjadikan pembelajaran lebih bermakna karena pembelajaran yang diperoleh siswa bermanfaat dalam kehidupan sehari-hari siswa. Untuk mendapatkan nilai-nilai kearifan Subak Abian Catu, bisa diupayakan dengan menggali lewat observasi, wawancara dan mencari dokumen yang ada pada masyarakat

Nilai-nilai kearifan lokal Subak Abian Catu meliputi : sikap hormat terhadap alam, tanggung jawab, solidaritas kosmis, kasih sayang dan keperdulian terhadap alam, tidak merugikan, hidup sederhana dan selaras dengan alam, keadilan, demokrasi dan integritas moral. Pembelajaran dengan mengintegrasikan nilai-nilai kearifan lokal atau pembelajaran 
dengan menjadikan lingkungan yang dekat dengan anak didik menjadikan pembelajaran lebih inovatif, menarik dan lebih bermakna.

Pemanfaatan lingkungan sebagai Sumber belajar salah satu upaya mendekatkan siswa pada lingkungan budayanya sendiri da nada upaya pelestarian nilai-nilai kearifan lokal.Pengintegrasian nilai-nilai kearifan lokal dapat dilakukan dengan memasukkan nilai-nilai kearifan lokal Subak dalam materi pembelajaran yang disesuaikan dengan materi inti atau pokok yang ada korelasinya yang diwujudkan dalam bentuk suplemen atau bahan ajar.

Secara umum saran yang dapat dirumuskan yaitu, (1) Kepada guru mata pelajaran IPS diharapkan dapat memanfatkan lingkungan yang dekat dengan siswa sebagai sumber belajar.Karena tanpa kita sadari banyak nilai-nilai kearifan lokal yang kita miliki yang perlu kita wariskan pada generasi penerus.Pembelajaran dengan pemanfaatan lingkungan menjadikan pembelajaran lebih inovatif dan bermakna. Bagi guru IPS, pemanfaatan lingkungan sekitar dan fenomena lainnya yang mendukung materi IPS, sekiranya dapat terus diupayakan untuk dikembangkan dalam pembelajaran IPS baik dalam bentuk suplemen materi, media, maupun sumber belajar. Hal tersebut mengingat laboratorium IPS adalah masyarakat dan lingkungan sekitar.2).Kepada Siswa diharapkan mampu memahami betapa tingginya nilai-nilai kearifan lokal dan mengimplementasikan nilai-nilai kearifan lokal Subak Abian Catu, kedalam prilaku masing-masing siswa yang bisa dimanfaatkan dalam kehidupan dimasyarakat.Pengenalan subak kepada generasi muda melalui pendidikan dianggap penting untuk dilaksanakan mengingat eksistensi subak di Bali semakin menurun karena generasi muda Bali semakin meninggalkan bidang pertanian. Salah satu upaya pembuatan sumber belajar berupahandout materi ini, dapat memberikan pengetahuan dan wawasan mengenai keberadaan subak di Bali secara umum. Sehingga pemahaman siswa tentang nilai-nilai kearifan lokal Subak bisa menjadi wawasan yang harus dilestarikan dan dijaga.3).Kepada Sekolah selalu mengupayakan agar para pendidik atau guru selalu berinovasi dalam pembelajaran, dengan memanfaatkan segala sumber yang ada pada lingkungan sekolah atau masyarakat untuk lebih meningkatkan variasi dan inovasi seorang guru sebagai upaya pembelajaran berlangsung dengan baik dan bermakna. Di samping itu produk pengembangan berupa handout materi tersebut, juga dapat disosialisasikan kepada guru lain demi memperkaya materi dan sumber belajar yang berwawasan lingkungan.4).Kepada Peneliti lainnya untuk melakukan penelitian lebih lanjut, agar memodifikasi penelitian ini sehingga diperoleh Hasil Belajar IPS yang lebih baik. Di samping itu dengan makin banyaknya penelitian yang sejenis akan memperkaya khasanah pendidikan dibidang pembelajaran utamanya pemanfaatan sumber belajar untuk meningkatkan upaya pembelajaran IPS

\section{DAFTAR RUJUKAN}

Akbar, Sa dun. 2006. Pengembangan Kurikulum IPS, Malang: Pascasarjana Universitas Kanjuruhan.

Arikunto, S. 2004. Dasar-dasar Evaluasi.Jakarta : Bumi Aksara

Fajarini, Ulfah. 2014. "Peranan Kearifan Lokal dalam Pendidikan Karakter". Jurnal Sosio Didaktika, Volume 1, Nomor 2 (hlm.123-130).

Gunawan, Rudy. 2013. Pendidikan IPS: Filosofi, Konsep, dan Aplikasi. Edisi Revisi. Bandung: Alfabeta.

Keraf, A Sony. 2002, Etika Lingkungan. Jakarta: PT Kompas Media Nusantara

Kertih, I Wayan.2015 .Perangkat Pembelajaran PPKn Perencanaan dan Pengembangan.Yogyakarta. Media Akademi

Prastowo,Andi,2014. Panduan Kreatif Membuat Bahan Ajar Inovatif.Yogyaakarta Diva Press 
Sani, Ridwan Abdulah. 2015. Pembelajaran Saintifik Untuk Implementasi Kurikulum 2013. Jakarta. Bumi Aksara

Somantri, M. N. (2001). Menggagas Pembaharuan Pendidikan IPS. Bandung: PT Remaja Posdakarya.

Sutawan, Nyoman. 2003. “Kearifan Lokal dalam Pengelolaam Sumberd Oktober 2003

Windia, W \& dkk.1997. Subak Sistem Irigasi Tradisional Sebuah Canangsari.Denpasar. Upada Sastra.

Windia, Wayan. 2006. Transformasi Sistem Irigasi Subak yang Berlandaskan Konsep Tri Hita Karana. Denpasar: Pustaka Bali Post. 